\title{
Enzymatic activities and arbuscular mycorrhizal colonization of Plantago lanceolata and Plantago major in a soil root zone under heavy metal stress
}

\author{
Ewa Gucwa-Przepióra $^{1}$ • Aleksandra Nadgórska-Socha ${ }^{2} \cdot$ Barbara Fojcik $^{1}$. \\ Damian Chmura ${ }^{3}$
}

Received: 2 July 2015 / Accepted: 26 October 2015 / Published online: 4 November 2015

(C) The Author(s) 2015. This article is published with open access at Springerlink.com

\begin{abstract}
The objectives of the present field study were to examine the soil enzyme activities in the soil root zones of Plantago lanceolata and Plantago major in different heavy metal contaminated stands. Moreover, the investigations concerned the intensity of root endophytic colonization and metal bioaccumulation in roots and shoots. The investigated Plantago species exhibited an excluder strategy, accumulating higher metal content in the roots than in the shoots. The heavy metal accumulation levels found in the two plantain species in this study were comparable to other plants suggested as phytostabilizers; therefore, the selected Plantago species may be applied in the phytostabilization of heavy metal contaminated areas. The lower level of soil enzymes (dehydrogenase, urease, acid, and alkaline phosphatase) as well as the higher bioavailability of metals in the root zone soil of the two plantain species were found in an area affected by smelting activity, where organic matter content in the soil was also the smallest. Mycorrhizal colonization on both
\end{abstract}

Responsible editor: Zhihong $\mathrm{Xu}$

Ewa Gucwa-Przepióra

egucwaprzepiora@gmail.com

Aleksandra Nadgórska-Socha

aleksandra.nadgorska-socha@us.edu.pl

Barbara Fojcik

fojcik@us.edu.pl

Damian Chmura

dchmura@ath.bielsko.pl

1 Department of Botany and Nature Protection, University of Silesia, Jagiellońska 28, 40-032 Katowice, Poland

2 Department of Ecology, University of Silesia, Bankowa 9, 40-007 Katowice, Poland

3 Institute of Engineering and Environmental Protection, University of Bielsko-Biała, Willowa 2, 43-309 Bielsko-Biała, Poland species in the contaminated area was similar to colonization in non-contaminated stands. However, the lowest arbuscule occurrence and an absence of dark septate endophytes were found in the area affected by the smelting activity. It corresponded with the lowest plant cover observed in this stand. The assessment of enzyme activity, mycorrhizal colonization, and the chemical and physical properties of soils proved to be sensitive to differences between sites and between Plantago species.

Keywords Plantago $\cdot$ Heavy metals $\cdot$ Soil enzymes $\cdot$ Mycorrhiza

\section{Introduction}

The trace metals released into the environment through human activities (such as smelting, energy and fuel production, power transmission, agriculture, foundries, and especially waste deposits from $\mathrm{Zn}-\mathrm{Pb}$ ore mining) have been reported to be dangerous to the ecosystems as well as their inhabitants - human beings (Nouri et al. 2009; Olowoyo et al. 2012; Wójcik et al. 2014). This type of environmental pollution may be indicated by some plants; thanks to their ability to absorb and accumulate metals with different accumulation strategies (Markert et al. 2008; Bekteshi and Bara 2013); this ability of autochthonous plant cover is also commonly used in the remediation of mine tailings (Olowoyo et al. 2012; Wójcik et al. 2014). Knowledge about the capabilities of plant species naturally occurring in contaminated areas to absorb and transport metals will provide information for choosing appropriate plants for phytoremediation purposes.

The two plantain species: Plantago lanceolata and Plantago major investigated in the study are representatives of the ruderals in natural vegetation in Poland. Ruderals are 
widely spread and recommended as bioaccumulation indicators with the ability to accumulate metals in large quantities without visible damage. The two plantain species are characterized by a tolerance to metal contaminants and other adverse site conditions connected with antioxidant defense, as discussed in a previous study (Nadgórska-Socha et al. 2013). $P$. lanceolata is still an object of many studies as an indicator of metals in shoots and in the soil (Tamás and Kovács 2005; Dimitrova and Yurukova 2005). It is strongly colonized by AM fungi, and mycorrhizal colonization of this plant has been proposed as a useful tool in the bioindication of soil quality and effectiveness of restoration processes (Orłowska et al. 2002, 2005, 2012). The other plantain species, P. major, has been postulated as a bioindicator, e.g., in a study of the Region of Durrës (Bekteshi and Bara 2013), and used in determining the efficacy of heavy metals bioaccumulation and translocation potential at a heavy traffic affected soil site (Galal and Shehata 2015). Despite the research on the accumulation ability of selected heavy metals in Cardaminopsis arenosa, $P$. lanceolata, and P. major leaves and antioxidative defense responses in metalliferous soil (Nadgórska-Socha et al. 2013; 2015), there is insufficient data on AM colonization by excluders - plantain species in field studies, especially in contaminated areas. The development of plant cover is important for the restoration of the physical, chemical, and biological properties of contaminated soils, which naturally reduce the mobility and bioavailability of heavy metals via sorption, precipitation, and complexation reactions (Pérez de Mora et al. 2005). Plants are additionally significant for soil biota through influencing the quality and quantity of organic substrates in the soil. The plant cover and organic matter content also play important roles in determining soil enzyme activity as extracellular enzymes are derived mainly from soil microorganisms, plant roots, and soil animals. Soil phosphatases are enzymes with a relatively broad specificity, capable of hydrolyzing various organic phosphate esters, and are involved in the P cycle (Dick 1997; Yang et al. 2010; Fernández et al. 2012). Dehydrogenase activity reflects the total oxidative activities of soil microflora, important in oxidizing soil organic matter (Dick 1997), and active inside the viable cells. The activity of dehydrogenase is similar to the number of active microorganisms. This enzyme has been considered as a sensitive indicator of soil quality and a valid biomarker to indicate changes in total microbial activity due to changes in soil management (Dick 1997; Kieliszewska-Rokicka 2001; Nadgórska-Socha et al. 2006; Fernández et al. 2012). Urease catalyzes the hydrolysis of urea into ammonia or ammonium ion depending on soil $\mathrm{pH}$ and carbon dioxide. An extracellular enzyme is affected by plant type or species combinations (Yang et al. 2007, 2010).
Heavy metals can affect microbial processes and decrease the number and activity of soil microorganisms among these arbuscular mycorrhizal fungi. However, long-term heavy metal effects can increase its tolerance to metals. Arbuscular mycorrhiza (AM) is the most ancestral and common type of mycorrhizal symbiosis (Brundrett 2002), in which the fungal hyphae penetrate the cortical cell wall of the host plant root. It is characterized by arbuscules and vesicles formed by the aseptate, obligate symbiotic fungi of the phylum Glomeromycota (Schüßler et al. 2001), which can play an important role in heavy metal stress mitigation as well as in the restoration of contaminated ecosystems (Gucwa-Przepióra and Turnau 2001; Pérez de Mora et al. 2005; GucwaPrzepióra et al. 2007; Yang et al. 2007). Moreover, there is evidence that AM fungi can benefit plant nutrition and enhance plant tolerance to heavy metal pollution, in part by immobilization of metals within or near the root and reducing their translocation to the shoot (Carrasco et al. 2011).

Dark septate root endophytes (DSE) are an artificial assemblage of fungi that have darkly pigmented septate hyphae and are frequent intracellular root associates of plants (Piercey et al. 2004). They colonize the cortical cells and intercellular regions of roots and form densely septated intracellular structures called microsclerotia (Jumpponen and Trappe 1998). Similarly to AM fungi, it might be possible that DSE colonization plays an important role in improving plant fitness (Addy et al. 2005; Likar and Regvar 2013).

When assessing the toxicity of contaminated soils, both heavy metal concentration and availability must first be determined. So far, information linking heavy metal bioavailability and toxicological response in soils has been very limited (Wang et al. 2007). In this work, we reported the results of a study carried out on P. lanceolata and $P$. major growing on heavy metal contaminated soils and on the heavy metal bioaccumulation and translocation efficiency. The aim of this study was to examine soil enzyme activity in soil root zones with different heavy metal contamination and the relationships between soil enzyme activity and selected heavy metal bioavailability. The investigations were undertaken to study the intensity of root endophytic colonization (AM and DSE) and metal bioaccumulation in roots and shoots. Furthermore, the application of soil enzyme activity and mycorrhizal colonization indices in bioindication field studies was discussed.

\section{Materials and methods}

\section{Study area}

The study was performed in three areas situated in the Śląkie and Małopolskie provinces in southern Poland. Two sites 
were contaminated with heavy metals: the vicinity of a former metal smelting plant "Szopienice" (Sz) in Katowice 50 $15^{\circ}$ $29.65^{\prime \prime} \mathrm{N}, 19^{\circ} 6^{\prime} 42.88^{\prime \prime} \mathrm{E}$, and a zinc-lead (calamine) site in

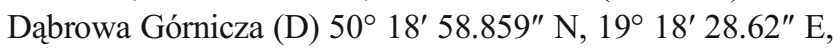
connected with ore mining and the processing of calamine zinc ores. The third locality was a non-contaminated area in the perimeter of the Pazurek Nature Reserve in Jaroszowiec (J) near Olkusz $50^{\circ} 19^{\prime} 58.74^{\prime \prime} \mathrm{N}, 19^{\circ} 35^{\prime} 59.82^{\prime \prime}$ E. The investigated stands were chosen due to the different metal content (the greatest in Dąbrowa Górnicza) and the origin of contamination in the soil (vicinity of smelter, calamine postmining area). The heavy metal content in these soils had been previously ascertained (Nadgórska-Socha et al. 2013). The estimated amounts of $\mathrm{Cd}$ in this study were $90.8 ; 301.2$; $2.7 \mathrm{mg} \mathrm{kg}^{-1}$, Zn 8403; 70,446, $359 \mathrm{mg} \mathrm{kg}^{-1}$; Pb 395, 3619, $123 \mathrm{mg} \mathrm{kg}^{-1}$ in Szopienice (Sz), Dabrowa Górnicza (D) and Jaroszowiec (J), respectively.

Plant cover at the three sites, according to the BraunBlanquet method, is given in Table 1. The analyzed areas differed in the degree of vegetation. In Dąbrowa Górnicza (D), the vegetation was almost seminatural, with a threelayered mixed forest (the first trees were planted in the 1970s). The area in the vicinity of non-ferrous metal smelter (Sz) was characterized by the sparsest plant coverage, and both in the site affected by smelting activity (Sz) and in noncontaminated area in Jaroszowiec (J) meadow plants prevailed (from the Molinio-Arrhenatheretea class).

\section{Plant and soil sampling}

The research was carried out on the shoots and roots of P. lanceolata and P. major collected during the period of flowering at the end of July 2014. At every sampling site, 20 randomly chosen plant individuals and soil samples (from the depth of $0-20 \mathrm{~cm}$ ) were collected in three replicates. The collected soil and plant samples were transferred to the laboratory. Plant samples were taken to the laboratory on ice, separated into shoots and roots, thoroughly washed with tap water to remove any substrate and dust deposits and then rinsed twice with deionized water. Soil samples were sieved through a 2-mm screen. Half of them were air dried and used for $\mathrm{pH}$ assessment, heavy metal content, and organic matter estimation, and the other half remained field moist to be used for soil enzyme analysis.

\section{Plant and soil analysis}

\section{Analysis of metal concentrations}

Soil $\mathrm{pH}$ was measured using a 1:2.5 soil to water ratio. Organic matter content (expressed in \%) was measured
Table 1 Structure of plant cover of analyzed areas

\begin{tabular}{llll}
\hline & Sz & D & J \\
\hline Coverage of tree layer in \% & - & 50 & - \\
Coverage of shrub layer in \% & - & 20 & - \\
Coverage of herb layer in \% & 60 & 70 & 90 \\
Coverage of bryophytes layer in \% & 4 & 60 & 3 \\
Total number of species & 21 & 32 & 18
\end{tabular}

Plant species in tree layer:

Acer platanoides

Larix decidua

Pinus sylvestris

Shrub layer:

Acer pseudoplatanus

Betula pendula

Corylus avellana

Fagus sylvatica

Padus serotina

Sorbus aucuparia

Herb layer ${ }^{\mathrm{a}}$ :

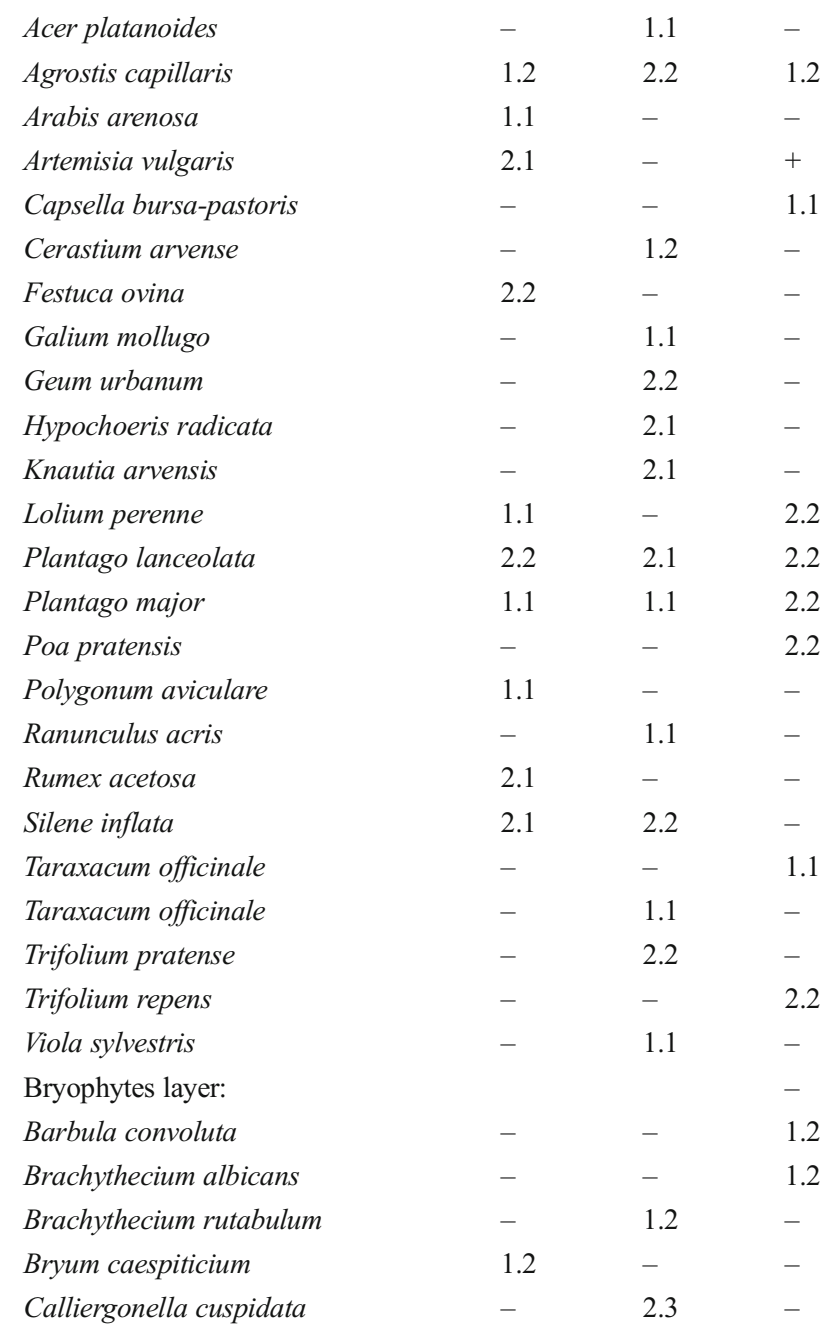


Table 1 (continued)

\begin{tabular}{llll}
\hline & Sz & D & J \\
\hline Plagiomnium cuspidatum & - & 3.3 & - \\
Weisia controversa & 1.3 & - & -
\end{tabular}

${ }^{\text {a }}$ Sporadic species in herb layer (+): Acer negundo (Sz), Acer pseudoplatanus (D), Achillea millefolium (Sz, J), Agropyron repens (Sz), Carex hirta (S3), Chamomilla suaveolens (S3), Daucus carota (Sz), Echium vulgare (Sz), Epipactis helleborine (D), Euphorbia cyparissias (D), Fraxinus pennsylvanica $(\mathrm{Sz})$, Hieracium pilosella $(\mathrm{Sz})$, Leontodon autumnalis $(\mathrm{Sz}$, J), Lotus corniculatus (Sz), Medicago sativa (J), Padus serotina (D), Pimpinella major (D), Pimpinella saxifrage (D), Potentilla argentea (J), Quercus robur (D), Scabiosa ochroleuca (D), Silene nutans (D), Sorbus aucuparia (D), Veronica arvensis (J)

following the method by Ostrowska et al. (1991). The concentrations of $\mathrm{Cd}, \mathrm{Pb}, \mathrm{Zn}, \mathrm{Cu}, \mathrm{Fe}, \mathrm{Mn}, \mathrm{K}, \mathrm{Mg}$, and $\mathrm{Ca}$ were analyzed. The metal content of the soil ( $\mathrm{HNO}_{3}$-extractable fraction) was estimated according to the method by Ostrowska et al. (1991) and previously described in detail (Nadgórska-Socha et al. 2013). An $\mathrm{HNO}_{3}$-extractable fraction from the soils was obtained by shaking a sample $(10 \mathrm{~g})$ with $100 \mathrm{ml}$ of $2 \mathrm{M} \mathrm{HNO}_{3}$ for $1 \mathrm{~h}$. The bioavailable fraction (potentially bioavailable elements) was obtained by shaking a soil sample (1:10) with $0.01 \mathrm{M} \mathrm{CaCl}_{2}$ for $2 \mathrm{~h}$ (Wójcik et al. 2014). The content of metals was measured in the filtered extracts using flame absorption spectrometry (Thermo Scientific iCE 3500).

Plant samples were oven dried at $105^{\circ} \mathrm{C}$, and dry weight subsamples $(0.25 \mathrm{~g})$ were wet digested in $\mathrm{HNO}_{3}$ at $110^{\circ} \mathrm{C}$ and then diluted to $25 \mathrm{ml}$ with deionized water. The content of metals was measured using flame absorption spectrometry (Thermo Scientific iCE 3500). For assurance of the quality of substrate analysis, the procedures were performed for blank samples and for certified reference materials.

\section{Metal accumulation efficiency}

To evaluate the metal accumulation efficiency in plants, we calculated mobility ratio (MR) and translocation factor (TF). TF is the ratio of metal concentration in shoots compared to the roots. $\mathrm{TF}>1$ indicates that a given element is efficiently translocated from the roots to shoots. MR is the ratio of metal concentration in shoots compared to the soil (Serbula et al. 2012).

\section{Soil enzymes and root acid phosphatase activity}

The soil enzymes activity was determined in soil samples at field moisture, sieved through a $2-\mathrm{mm}$ sieve and stored at $4{ }^{\circ} \mathrm{C}$ before microbial analysis. The activity of alkaline and acid phosphatase was measured according to the method of Schinner et al. (1995). The p-nitrophenol (p-NP) released by phosphomonoesterase activity was extracted and colored with sodium hydroxide and determined photometrically at $400 \mathrm{~nm}$. The phosphatase activity was expressed in $\mu \mathrm{g} \mathrm{p}-\mathrm{NP} \mathrm{g}^{-1} \mathrm{dm} \mathrm{h}{ }^{-1}$. The urease activity estimation was based on the colorimetric determination of ammonium formation after enzymatic urea hydrolysis (10\% solution, $\lambda-630 \mathrm{~nm})$. Urease activity was expressed as $\mu \mathrm{g} \mathrm{N} \mathrm{g}^{-1} \mathrm{dm}$. Triphenyltetrazolium chloride was the substrate used for dehydrogenase activity determination. The produced triphenyl formazan (TPF) was extracted with acetone and measured photometrically at $546 \mathrm{~nm}$. The dehydrogenase activity was expressed in $\mu \mathrm{g}$ TPF $\mathrm{g}^{-1} \mathrm{dm} 16 \mathrm{~h}^{-1}$ (Schinner et al. 1995).

Acid phosphatase analysis was performed on fresh root samples according to Aery (2010). One gram of roots was ground in 5-ml chilled acetate buffer and centrifuged at 15, $000 \times g$ for $10 \mathrm{~min}$. Supernatants were used as the enzyme source. After $30 \mathrm{~min}$, incubation at $35^{\circ} \mathrm{C}$ with substrate solution (p-nitrophenyl phosphate in acetate buffer), the reaction was terminated by adding $0.1 \mathrm{M} \mathrm{NaOH}$ and absorbance was measured at $410 \mathrm{~nm}$. Enzyme activity was expressed as $\mu \mathrm{mol}$ of $\mathrm{p}-\mathrm{NP}$ released $\mathrm{min}^{-1} \mathrm{~g}^{-1} \mathrm{fw}$.

To compare the heavy metal effects between contaminated soils, enzymes activity ratio (ACR) in \% was introduced according to Xian et al. (2015):

$\mathrm{ACR}=\left(A_{h}-A_{c}\right) / A_{c} \times 100 \%$

$A_{h}$ and $A_{c}$ denote enzyme activity in metal polluted (Sz and D) and control soil (J).

\section{Mycorrhizal studies}

For the estimation of mycorrhizal development, the roots were prepared according to a modified method of Phillips and Hayman (1970). After being careful washed in tap water, the roots were softened in $7 \% \mathrm{KOH}$ for $24 \mathrm{~h}$ and then rinsed in a few changes of water. The material was acidified in $5 \%$ lactic acid for $24 \mathrm{~h}$ and then stained with $0.01 \%$ aniline blue in lactic acid for $24 \mathrm{~h}$. The entire procedure was carried out at room temperature.

The following parameters describing the intensity and effectiveness of the mycorrhization were recorded: mycorrhizal frequency $(\mathrm{F} \%)$ - the ratio between root fragments colonized by AMF mycelium and the total number of root fragments analyzed; relative mycorrhizal root length (M\%) - an estimate of the amount of root cortex that was mycorrhizal relative to the whole root system; the intensity of colonization within individual mycorrhizal roots $(\mathrm{m} \%)$; relative arbuscular richness $(\mathrm{A} \%)$ - arbuscule richness in the whole root system and arbuscule richness in root fragments where arbuscules were present $(\mathrm{a} \%)$ (Trouvelot et al. 1986). 
DSE colonization was identified on the basis of regularly septate hyphae, usually dark pigmented, with facultatively occurring sclerotia (Jumpponen 2001).

\section{Data analysis}

The two-way ANOVA was applied to examine the effect of a species and site on various variables, including the concentrations of metals in soils and plants, $\mathrm{pH}$ value and organic matter content, soil enzymes activity from root zone, root phosphatase activity, and mycorrhizal colonization indices. The Tukey's test was used for multiple comparisons. To this end, based on the interactions of species and sites, six groups were distinguished which were further tested for significance of differences in the aforementioned variables. In relation to $\mathrm{pH}$, the non-parametrical Kruskal-Wallis test followed by the Conover test for pairwise comparisons was used. The Pearson correlation test was employed to assess the significance of relationships between soil enzymes activity from root zone, root phosphatase activity, mycorrhizal colonization indices, and the properties of soils. All calculations were performed in $\mathrm{R}$ language and environment ( $\mathrm{R}$ Core Team 2014).

\section{Results}

Two-way ANOVA revealed that with regards to the interactions between species and sites, all cases of concentrations of metals in root zone turned out to be significant (Table 2). The contents of $\mathrm{Mn}, \mathrm{Zn}$, and $\mathrm{Mg}$, Ca did differ among six groups based on species $x$ site interactions (Table 2). The results are presented in details below.

\section{Root zone soil properties}

The soil most contaminated with the examined metals was found in the mining activity area (D). Similar amounts of Cd were evaluated in root zone for both species of plantain (Table 3). Moreover in this stand, the highest $\mathrm{Cu}, \mathrm{Pb}$, and $\mathrm{Zn}$ content were characterized for the soil root zone of $P$. lanceolata, and for $\mathrm{Fe}$ and $\mathrm{Mn}$, the highest concentrations in root zone soil were found for P. major. The bioavailable content of the examined metals was very low in comparison to the $\mathrm{HNO}_{3}$ extracted metal concentration, as listed in Table 3. $\mathrm{pH}$ values of the soils collected in the contaminated areas were above 7. Organic matter content was the highest in the soil samples from the site affected by mining activity (D).

\section{Metal bioaccumulation in roots and shoots}

Metal bioaccumulation was analyzed in shoots and in roots of P. lanceolata and P. major (Table 4). The highest Fe content in shoots and in roots were found in the plants collected in the mining activity area (D). The highest $\mathrm{Zn}$ contents in shoots and in roots were found in $P$. lanceolata in the site affected by smelting activity (Sz) and in $P$. major in the area affected by mining activity (D). The highest bioaccumulation of $\mathrm{Cd}$ in the shoots was noticed in P. major. Comparing the bioaccumulation ability of the two investigated species, higher concentrations of $\mathrm{Cd}, \mathrm{Fe}$, and $\mathrm{Zn}$ were evaluated in the roots of P. lanceolata than P. major (Table 4). The values of mobility ratio (MR) for all the metals in shoots from contaminated areas showed that their absorption from the soil was not considerable. The MR values in P. lanceolata in the area affected by smelting activity (Sz) and in the site affected by mining activity (D) were for $\mathrm{Cd} 0.71,0.04 ; \mathrm{Cu} 0.1,0.08 ; \mathrm{Pb} \mathrm{0.15}$, $0.03, \mathrm{Mn} 0.36 ; 0.03 ; \mathrm{Zn} 0.28,0.02$. In P. major, the MR values were in the same contaminated sites as follows: $\mathrm{Cd} 1.36,0.14$; $\mathrm{Cu}$ 0.16, 0.10; Pb 0.1, 0.6, Fe 0.65, 0.27; Mn 0.16, 0.05; Zn $0.27,0.03$. It confirms the low mobility of metals in soils with $\mathrm{pH}$ value over 7. In addition, a value of MR higher than 1 was characteristic for $\mathrm{Cd}$ and $\mathrm{Fe}$ computed for roots of both species. Effective translocation ( $\mathrm{TF}>1)$ was not observed for the shoots of either species from the contaminated area.

\section{Soil enzyme activities}

Generally, root zone soils of both species collected in the site impacted by mining activity (D) were characterized by the highest enzyme activity (Fig. 1a-d). Soils from the root zone of $P$. lanceolata were characterized by the highest acid and alkaline phosphatase. In turn, the highest dehydrogenase and similar urease activity was observed in root zone soil samples of P. major in the same area. A lower activity of soil phosphatases, dehydrogenase as well as urease was found in the area impacted by smelting activity (Sz) in root zone soils of both species in comparison to soil from the uncontaminated control area.

To compare the heavy metal effects between the different contaminated soils (mining and smelting activity), an enzyme activity change ratio (ACR) was investigated. ACR depicts the relative toxicity of investigated soil to enzyme activity. A positive ACR in the area impacted by mining activity (D) denoted that enzyme activity was enhanced, and a negative ACR in the area impacted by smelting activity (Sz) denoted that enzyme activity was restricted (Table 5). ACR for the investigated soil enzymes varied from -67.6 to 424.4 for P. lanceolata root zone soil and from -85.6 to 136.9 for P. major root zone soil.

Positive correlation coefficients were obtained between the examined soil enzymes and metals extracted with $\mathrm{HNO}_{3}$ (Table 6). Also, positive correlation coefficients were obtained between investigated enzymes activity and bioavailable Mn content in soil from the root zone of $P$. lanceolata. Soil enzymes activity was positively correlated to organic matter content. 
Table 2 Effect of site, species on heavy metals in soils and in studied plants, pH, organic matter, soil enzymes, root phosphatase activity, and mycorrhizal colonization indices (two-way ANOVA and "Kruskal-Wallis test)

\begin{tabular}{|c|c|c|c|c|c|c|c|c|c|}
\hline \multirow[t]{2}{*}{ Variable } & \multicolumn{3}{|c|}{ Species } & \multicolumn{3}{|c|}{ Site } & \multicolumn{3}{|c|}{ Species $\mathrm{x}$ site } \\
\hline & $d$ & $F$ & $p$ & $d$ & $F$ & $p$ & $d$ & $F$ & $p$ \\
\hline $\mathrm{Cd}$ & 1 & 3.12 & 0.10259 & 2 & 3091.89 & $<0.00001$ & 2 & 5.99 & 0.01569 \\
\hline $\mathrm{Cu}$ & 1 & 391.89 & $<0.00001$ & 2 & 474.47 & $<0.00001$ & 2 & 255.66 & $<0.00001$ \\
\hline $\mathrm{Pb}$ & 1 & 19.84 & 0.0007872 & 2 & 7354.97 & $<0.00001$ & 2 & 13.77 & $<0.00001$ \\
\hline $\mathrm{Fe}$ & 1 & 153.02 & $<0.00001$ & 2 & 2630.26 & $<0.00001$ & 2 & 80.77 & $<0.00001$ \\
\hline $\mathrm{Mn}$ & 1 & 145.64 & $<0.00001$ & 2 & 7909.86 & $<0.00001$ & 2 & 47.21 & $<0.00001$ \\
\hline $\mathrm{Zn}$ & 1 & 169.76 & $<0.00001$ & 2 & 13120.02 & $<0.00001$ & 2 & 97.15 & $<0.00001$ \\
\hline Cd bioavailable & 1 & 245.58 & $<0.00001$ & 2 & 334.12 & $<0.00001$ & 2 & 209.13 & $<0.00001$ \\
\hline $\mathrm{Pb}$ bioavailable & 1 & 1.76 & 0.2088 & 2 & 0.56 & 0.5829 & 2 & 0.29 & 0.7471 \\
\hline Mn bioavailable & 1 & 150.24 & $<0.00001$ & 2 & 179.33 & $<0.00001$ & 2 & 36.62 & $<0.00001$ \\
\hline Zn bioavailable & 1 & 321.26 & $<0.00001$ & 2 & 247.25 & $<0.00001$ & 2 & 413.12 & $<0.00001$ \\
\hline $\mathrm{pH}^{\#}$ & - & - & - & - & - & - & 5 & 15.72 & 0.007687 \\
\hline Organic matter & 1 & 13.76 & 0.002988 & 2 & 425.81 & $<0.00001$ & 2 & 28.05 & $<0.0001$ \\
\hline Cd shoot & 1 & 227.54 & $<0.00001$ & 2 & 836.23 & $<0.00001$ & 2 & 106.03 & $<0.0001$ \\
\hline $\mathrm{Cu}$ shoot & 1 & 57.89 & $<0.00001$ & 2 & 116.30 & $<0.00001$ & 2 & 26.43 & $<0.0001$ \\
\hline $\mathrm{Pb}$ shoot & 1 & 0.044 & 0.8362 & 2 & 165.67 & $<0.00001$ & 2 & 74.78 & $<0.00001$ \\
\hline Fe shoot & 1 & 38.80 & $<0.00001$ & 2 & 157.10 & $<0.00001$ & 2 & 4.31 & 0.03891 \\
\hline Mn shoot & 1 & 1.64 & 0.2247 & 2 & 245.52 & $<0.00001$ & 2 & 155.61 & $<0.00001$ \\
\hline Zn shoot & 1 & 43.20 & $<0.00001$ & 2 & 359.95 & $<0.00001$ & 2 & 35.53 & $<0.00001$ \\
\hline $\mathrm{Cd}$ root & 1 & 110.22 & $<0.00001$ & 2 & 161.95 & $<0.00001$ & 2 & 25.73 & $<0.0001$ \\
\hline $\mathrm{Cu}$ root & 1 & 23.56 & 0.0003959 & 2 & 51.34 & $<0.00001$ & 2 & 39.87 & $<0.00001$ \\
\hline $\mathrm{Pb}$ root & 1 & 7.46 & 0.0182 & 2 & 1655.75 & $<0.00001$ & 2 & 187.85 & $<0.00001$ \\
\hline Fe root & 1 & 100.19 & $<0.00001$ & 2 & 1344.46 & $<0.00001$ & 2 & 6.36 & 0.01308 \\
\hline Mn root & 1 & 11.54 & 0.005301 & 2 & 11.54 & 0.005301 & 2 & 2.87 & 0.095584 \\
\hline Zn root & 1 & 27.94 & 0.0001927 & 2 & 260.90 & $<0.00001$ & 2 & 3.24 & 0.0749024 \\
\hline Mg shoot & 1 & 192.64 & $<0.00001$ & 2 & 80.89 & $<0.00001$ & 2 & 74.59 & $<0.00001$ \\
\hline Ca shoot & 1 & 26.08 & 0.0002588 & 2 & 0.713 & 0.5099726 & 2 & 0.31 & 0.7383411 \\
\hline K shoot & 1 & 0.17 & 0.688525 & 2 & 353.97 & $<0.00001$ & 2 & 11.58 & 0.001583 \\
\hline $\mathrm{Mg}$ root & 1 & 821.41 & $<0.00001$ & 2 & 391.87 & $<0.00001$ & 2 & 0.34 & 0.7217 \\
\hline Ca root & 1 & 3.91 & 0.07138 & 2 & 24.91 & $<0.0001$ & 2 & 0.62 & 0.55396 \\
\hline $\mathrm{K}$ root & 1 & 85.67 & $<0.00001$ & 2 & 114.46 & $<0.00001$ & 2 & 20.23 & 0.0001432 \\
\hline Alkaline phosphatase & 1 & 112.63 & $<0.00001$ & 2 & 10333.65 & $<0.00001$ & 2 & 594.17 & $<0.00001$ \\
\hline Dehydrogenase & 1 & 535.19 & $<0.00001$ & 2 & 2563.93 & $<0.00001$ & 2 & 238.03 & $<0.00001$ \\
\hline Acid phosphatase & 1 & 306.42 & $<0.00001$ & 2 & 877.37 & $<0.00001$ & 2 & 302.87 & $<0.00001$ \\
\hline Urease & 1 & 207.54 & $<0.00001$ & 2 & 2266.67 & $<0.00001$ & 2 & 157.15 & $<0.00001$ \\
\hline Root acid phosphatase & 1 & 368.42 & $<0.00001$ & 2 & 206.4 & $<0.00001$ & 2 & 43.53 & $<0.00001$ \\
\hline$F$ & & 0.0 & 1.0000 & 2 & 0.5 & 0.6186 & 2 & 1.5 & 0.2621 \\
\hline$M$ & & 0.06 & 0.8093 & 2 & 1.73 & 0.2184 & 2 & 0.80 & 0.4700 \\
\hline$m$ & & 0.07 & 0.7994 & 2 & 1.54 & 0.2531 & 2 & 0.94 & 0.4167 \\
\hline$a$ & & 3.42 & 0.0891 & 2 & 1.73 & 0.2192 & 2 & 0.65 & 0.5394 \\
\hline$A$ & & 1.7896 & 0.2058 & 2 & 2.6259 & 0.1133 & 2 & 0.2045 & 0.8179 \\
\hline
\end{tabular}

\section{Root phosphatase activity}

The root acid phosphatase activity was higher in P. major plants collected in the area disturbed by mining activity (D) comparing to the plants collected in area disturbed by smelting activity (Sz) and similar to plants from the control area (Fig. 2). ACR for root acid phosphatase varied from -25.7 to 1.93 for P. lanceolata and from 42.4 to 7.71 for $P$. major (Table 5). Root acid phosphatase was positively correlated to organic matter in the soil (Table 6). Negative correlation 
Table 3 Heavy metals concentration, $\mathrm{pH}$, and organic matter content in root zone soil of P. lanceolata and P. major

\begin{tabular}{|c|c|c|c|c|c|c|c|c|c|c|c|c|}
\hline \multirow[t]{2}{*}{ Species } & \multirow[t]{2}{*}{ Site } & \multicolumn{6}{|c|}{$\mathrm{HNO}_{3}$ extracted } & \multicolumn{3}{|c|}{ Bioavailable } & \multirow[t]{2}{*}{$\mathrm{pH}$} & \multirow[t]{2}{*}{ Organic matter conten } \\
\hline & & $\mathrm{Cd}$ & $\mathrm{Cu}$ & $\mathrm{Pb}$ & $\mathrm{Fe}$ & $\mathrm{Mn}$ & $\mathrm{Zn}$ & $\mathrm{Cd}$ & $\mathrm{Mn}$ & $\mathrm{Zn}$ & & \\
\hline \multirow[t]{3}{*}{ P.lanceolata } & $\mathrm{Sz}$ & $15.23 \mathrm{~b}$ & $42.46 \mathrm{~b}$ & $323.17 \mathrm{c}$ & $921.01 \mathrm{c}$ & $182.23 \mathrm{~b}$ & $2723.84 \mathrm{c}$ & $1.03 \mathrm{a}$ & $0.73 b$ & $14.10 \mathrm{a}$ & $7.49 \mathrm{c}$ & $5.50 \mathrm{~d}$ \\
\hline & $\mathrm{D}$ & $69.28 \mathrm{a}$ & $122.65 \mathrm{a}$ & $809.24 \mathrm{a}$ & $2250.78 \mathrm{~b}$ & $1247.76 \mathrm{~d}$ & $28836.11 \mathrm{a}$ & $0.22 \mathrm{~b}$ & $0.47 \mathrm{a}$ & $1.42 \mathrm{~d}$ & $7.55 \mathrm{~b}$ & $17.07 \mathrm{~b}$ \\
\hline & $\mathrm{J}$ & $0.79 \mathrm{~d}$ & $8.31 \mathrm{~d}$ & $34.48 \mathrm{e}$ & $343.74 \mathrm{e}$ & $48.41 \mathrm{e}$ & $342.10 \mathrm{e}$ & $0.25 \mathrm{c}$ & $1.26 \mathrm{~cd}$ & $4.54 \mathrm{c}$ & $6.04 \mathrm{~d}$ & $9.67 \mathrm{c}$ \\
\hline \multirow[t]{3}{*}{ P. major } & $\mathrm{Sz}$ & $10.15 \mathrm{c}$ & $28.86 \mathrm{c}$ & $293.42 \mathrm{~d}$ & $848.31 \mathrm{c}$ & $273.22 \mathrm{c}$ & $1727.75 \mathrm{~d}$ & $0.24 \mathrm{~b}$ & $0.64 \mathrm{c}$ & $7.59 \mathrm{~b}$ & $7.63 \mathrm{a}$ & $3.23 \mathrm{~d}$ \\
\hline & $\mathrm{D}$ & $69.86 \mathrm{a}$ & $29.28 \mathrm{c}$ & $758.31 \mathrm{~b}$ & $2966.75 \mathrm{a}$ & $1477.58 \mathrm{a}$ & $24086.82 \mathrm{~b}$ & $0.07 \mathrm{~b}$ & $0.39 \mathrm{~b}$ & $3.05 \mathrm{c}$ & $7.62 \mathrm{a}$ & $22.87 \mathrm{a}$ \\
\hline & $\mathrm{J}$ & $1.25 \mathrm{~d}$ & $7.63 \mathrm{~d}$ & $47.47 \mathrm{e}$ & $641.16 \mathrm{~d}$ & $61.53 \mathrm{e}$ & $348.04 \mathrm{e}$ & $0.04 \mathrm{c}$ & $0.31 \mathrm{~d}$ & $0.50 \mathrm{e}$ & $6.26 \mathrm{~d}$ & $11.03 \mathrm{c}$ \\
\hline
\end{tabular}

The different letters denote significant differences between particular metal concentrations in the $\mathrm{HNO}_{3}$ extracted and bioavailable fraction, organic matter content and $\mathrm{pH}$ value $(p<0.05)$

coefficients were obtained between root acid phosphatase in $P$. lanceolata and soil bioavailable $\mathrm{Cd}$ and $\mathrm{Zn}$ concentrations (Table 6).

\section{Mycorrhizal colonization}

Arbuscular mycorrhizae with arbuscules, which are the structural and functional criterion of symbiosis, were found in the roots of both analyzed Plantago species in all studied stands. In addition to the arbuscules, vesicles and coils were also present. All of the plants examined showed the Arum-type morphotype in which AM fungi most often colonize the inner cortex cells and arbuscules are formed terminally. In roots of both plantains, coarse AM fungi (hyphae diameter above $2 \mu \mathrm{m}$ ) were mostly found. Fine endophyte (Glomus tenue) was observed only in P. lanceolata roots from Dąbrowa Górnicza. The roots in both Plantago species were almost fully colonized by the AM mycelium (F\% ranged from 98 to $100 \%$ ) (Fig. 3a). Roots of plantains from contaminated (D, $\mathrm{Sz}$ ) and non-contaminated (J) areas showed no statistically significant differences in mycorrhizal colonization. However, the lowest root colonization (M\%, $\mathrm{m} \%$ ) was found in P. major and P. lanceolata in the area affected by mining activity (D) (Fig. 3b, c). In terms of arbuscule richness, the highest values of both measures of root arbuscule occurrence ( $\mathrm{A} \%$ and $\mathrm{a} \%$ ) in both investigated species were high in all the investigated sites. Arbuscule abundance in the whole root system (A\%) exceeded $60 \%$, whereas arbuscule richness of the colonized root section ( $\mathrm{a} \%)$ was over $50 \%$. The lowest arbuscule occurrence was found in Szopienice, the area affected by smelting activity (Fig. 3d, e).

The richness of mycorrhizal structures in the roots varied only slightly between plantains species. In the case of $P$. lanceolata, the intensity of root colonization $(\mathrm{M} \%, \mathrm{~m} \%)$ was higher in areas affected by mining and smelting activity compared to $P$. major, which was higher in the uncontaminated site. In contrast, average arbuscule abundance was higher in $P$. major in all studied stands when compared to P. lanceolata (Fig. 3).

All mycorrhizal indices were negatively correlated with the bioavailable contents of $\mathrm{Zn}, \mathrm{Cd}$, and $\mathrm{Mn}$ and with other metal concentrations in the soil (extracted with $\mathrm{HNO}_{3}$ ), while only statistically significant in terms of the richness of arbuscules in mycorrhizal root fragments ( $\mathrm{a} \%)$ in P. lanceolata roots and bioavailable $\mathrm{Zn}$ and $\mathrm{Cd}$ soil content, as well as between the intensity of root colonization $(\mathrm{M} \%, \mathrm{~m} \%)$ in roots of P. major and $\mathrm{Cu}$ and bioavailable $\mathrm{Mn}$ concentration in the soil (Table 6). $\mathrm{Cd}, \mathrm{Pb}$, and $\mathrm{Zn}$ concentrations in roots and shoots were negatively correlated with mycorrhizal colonization indices in roots of both investigated plantains (however, not all correlation coefficients were statistically significantly).

\section{DSE colonization}

DSE were found in both investigated plant species. However, they were not present in all the root samples. The mycelium was brownish and did not stain with aniline blue but remained brownish. DSE were observed in the cortex together with AMF but mainly in root fragments where arbuscules were absent. Only single hyphae, accompanied sporadically by sclerotia, were found in the rhizodermis and outer cortical cells. DSE were not observed in the roots of $P$. lanceolata or $P$. major from Szopienice, the site affected by smelting activity.

\section{Discussion}

In our work, we present a detailed report of soil enzymatic activities in the rhizosphere and arbuscular mycorrhizal colonization in roots of P. lanceolata and P. major in the areas affected by mining and smelting activity in southern Poland. Such field studies are needed for the verification of results obtained under controlled conditions. 
Metal concentrations in the investigated areas (D and Sz) definitely exceeded the average concentrations and limit values in the soil. $\mathrm{Zn}$ concentration in the soil root zone of P. lanceolata and P. major in the non-contaminated site (J) slightly exceeded the permissible concentration. Under natural conditions, soil levels of $\mathrm{Zn}$ usually fall in the range 10 $300 \mathrm{mg} \mathrm{kg}^{-1}$. The mean $\mathrm{Pb}$ concentration for surface soils on a world scale is estimated at $25 \mathrm{mg} \mathrm{kg}^{-1}$ and the average content of $\mathrm{Cd}$ in soils between 0.06 and $1.1 \mathrm{mg} \mathrm{kg}^{-1}$ (KabataPendias 2001). However, as reported in the Regulation by the Polish Minister of the Environment (2002), the limit values (permissible concentrations) of heavy metal content in soils are $\mathrm{Zn}-300 \mathrm{mg} \mathrm{kg}^{-1}, \mathrm{~Pb}-100 \mathrm{mg} \mathrm{kg}^{-1}$, and $\mathrm{Cd}-4 \mathrm{mg} \mathrm{kg}^{-1}$.

In our study, Plantago species exhibited higher metal concentrations in the roots than the corresponding shoot sample. Similar results were obtained for plants occurring on toxic mine tailings in Chenzhou City, Hunan Province, and a control site in Hong Kong in a work by Leung et al. (2007). Also, very low values of mobility ratio (syn. bioconcentration factor below $0.006,0.002$, and 0.02 for $\mathrm{Zn}, \mathrm{Pb}$, and $\mathrm{Cd}$, respectively) in P. lanceolata were obtained by Wójcik et al. (2014) investigating waste deposits $(\mathrm{Zn}-\mathrm{Pb})$ in Brzeziny Śląskie and Bolesław (southern Poland). In that study, P. lanceolata accumulated in shoots the following ranges of the $\mathrm{Zn}, \mathrm{Pb}, \mathrm{Cd}, \mathrm{Cu}$, respectively, 80.7-444; 3.4-38.2, $0.3-7.1$, and 5.1$14.5 \mathrm{mg} \mathrm{kg}^{-1}$ (Wójcik et al. 2014). The accumulated amounts of the above-mentioned metals in our study were higher for $\mathrm{Zn}, \mathrm{Pb}, \mathrm{Cd}$ and similar for $\mathrm{Cu}$. Plants selected for phytostabilization should be characterized by a low accumulation of metals in the above ground parts, restricted metal translocation from roots to shoots, dense canopies, and root system with a fast growth and high tolerance to metal contaminants and other adverse site conditions (Ernst 2005; Wójcik et al. 2014). Wójcik et al. (2014) suggested some plants for such protective treatment, with the following $\mathrm{Zn}, \mathrm{Cd}$, and $\mathrm{Pb}$ accumulation in the shoots of Calamagrostis epigejos (36-91; $\left.0.2-3 ; 6-11 \mathrm{mg} \mathrm{kg}^{-1}\right)$, Carex hirta $(72-275 ; 0.6-7,18 ; 2-$ $\left.19 \mathrm{mg} \mathrm{kg}^{-1}\right)$, Dianthus carthusianorum (152-463.4; 3.5 $\left.10.5 ; 3-11 \mathrm{mg} \mathrm{kg}^{-1}\right)$, Thymus pulegioides (109-445; $0.3-$ $\left.1.2 ; 4.8-40 \mathrm{mg} \mathrm{kg}^{-1}\right)$; Scabiosa ochroleuca (108-569; 0.33; 3-55), and Trifolium repens (90-207.6, 0.2-0.9, $3 \mathrm{mg} \mathrm{kg}^{-1}$ ). Metal accumulation in the two Plantago species in our investigation was inside the ranges mentioned above. Moreover, in our extensive study, we found some direct positive correlations between the amount of heavy metals in the soil and bioaccumulation in roots and shoots of the plants. In addition, a higher correlation coefficient between metal accumulation in soil and in roots was observed, especially for $\mathrm{Pb}$. All these characteristics of $P$. lanceolata and P. major, in addition to high mycorrhizal colonization, as well as tolerance to metal contaminants and other adverse site conditions connected with antioxidant defense (Nadgórska-Socha et al. 2013), make them potentially effective phytostabilizers. 

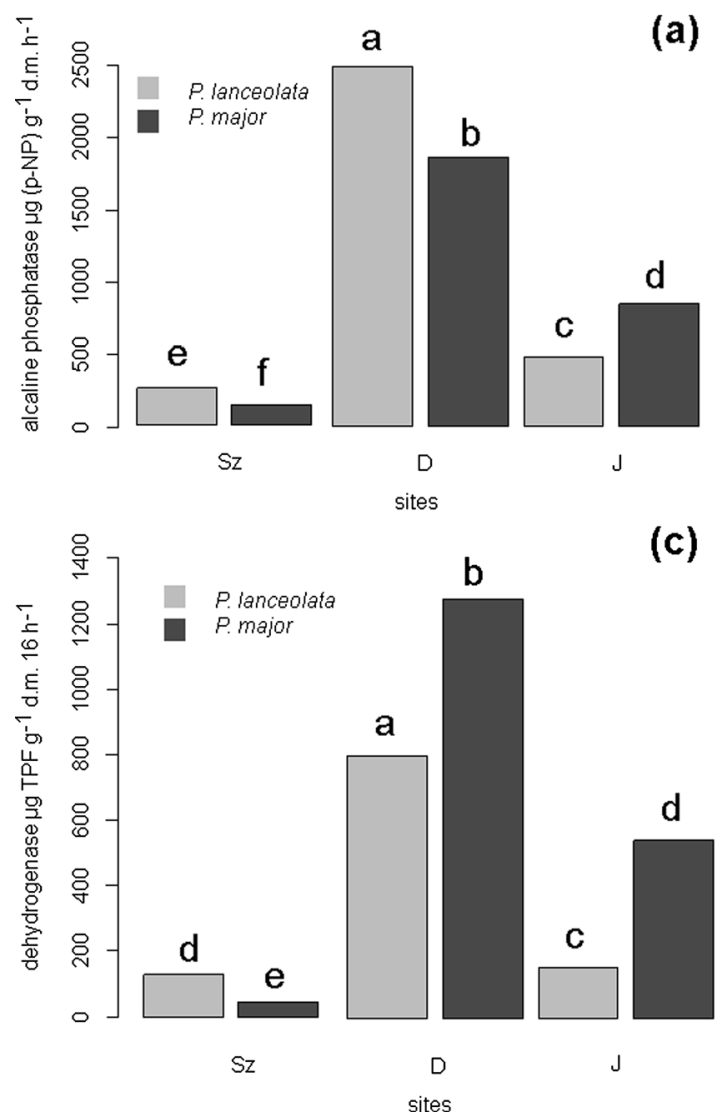

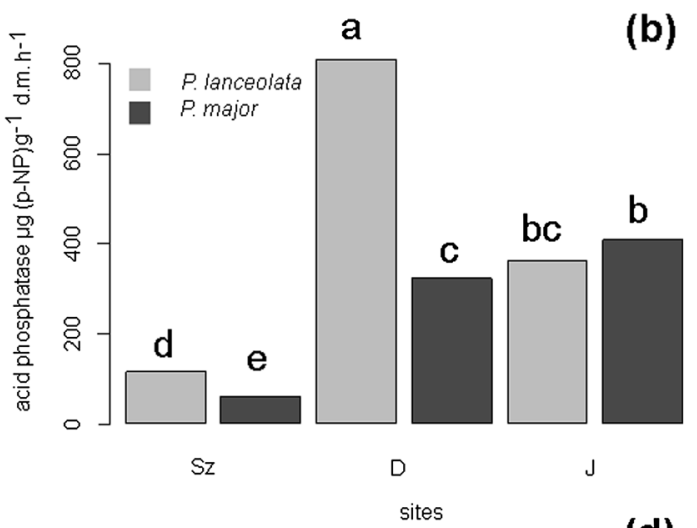

(d)

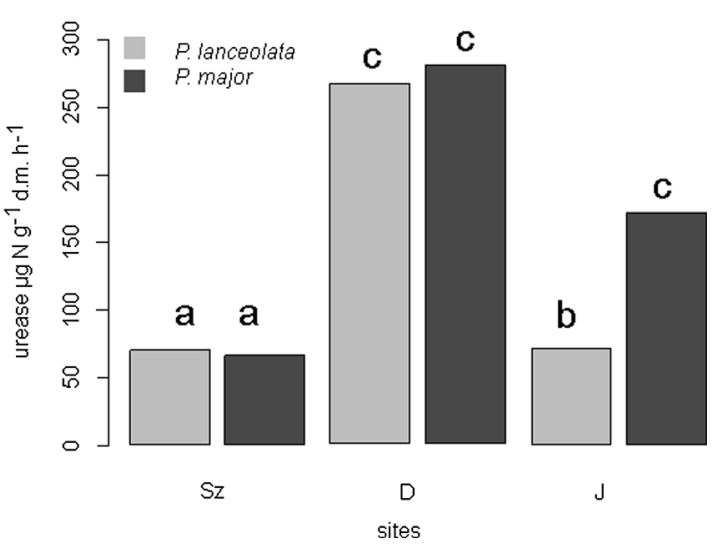

Fig. 1 (a-d) Soil enzyme activity in root zone of Plantago species. a Alkaline phosphatase, $\mathbf{b}$ acid phosphatase, $\mathbf{c}$ dehydrogenase, $\mathbf{d}$ urease. The different letters denote significant differences between enzymes activity $(p<0.05)$

Root phosphatases catalyze the hydrolysis of various phosphate esters increasing $\mathrm{P}$ available to plants and thus enhancing plant uptake (Carrasco et al. 2011). The soils in the investigated areas were characterized by small amounts of $\mathrm{P}$ extracted with $\mathrm{HNO}_{3}\left(\mathrm{D}-3.3, \mathrm{Sz}-185, \mathrm{~J}-267.5 \mathrm{mg} \mathrm{kg}{ }^{-1}\right)$ (Nadgórska-Socha et al. 2015). Generally, in our study, we found a positive correlation coefficient between mycorrhizal colonization and root phosphatase activity, although not statistically significant. In a study by Carrasco et al. 2011, mycorrhizal and fungal inoculation enhanced the phosphatase in the root of Coronilla juncea cultivated in soil from mine tailings. Increased root phosphatase activity under heavy metal stress is one of the possible processes involved in detoxification and resistance (Carrasco et al. 2011). In our study, decreased or the same activity of root phosphatase in plantains from contaminated areas was observed in comparison to the activity in the control site. Therefore, heavy metal phosphatase activity inhibition seems to depend on the plant species and metal concentration.

Soil enzymes activity is often used as an indicator of the functioning of soil ecosystems as well as anthropogenic input in soil environments. Moreover, enzyme activity can be used to show the effectiveness of soil rehabilitation treatments or to reflect soil quality that was destroyed by industrial processes (Ciarkowska et al. 2014). Ciarkowska et al. 2014 show that a high organic matter content as well as neutral $\mathrm{pH}$ transform

Table 5 Multiple comparison of enzyme activity change ratios (ACR) [\%] in the root and root zone soil of P. lanceolata and P. major

\begin{tabular}{lllllll}
\hline Species & Contaminated site & Alkaline phosphatase & Acid phosphatase & Dehydrogenase & Urease & Root acid phosphatase \\
\hline P.lanceolata & $\mathrm{Sz}$ & $-47.06 \mathrm{c}$ & $-67.63 \mathrm{c}$ & $-17.23 \mathrm{c}$ & $-0.98 \mathrm{c}$ & $-25.74 \mathrm{~b}$ \\
P. major & $\mathrm{Sz}$ & $-83.87 \mathrm{~d}$ & $-85.60 \mathrm{~d}$ & $-91.85 \mathrm{~d}$ & $-61.83 \mathrm{~d}$ & $-42.41 \mathrm{c}$ \\
P.lanceolata & $\mathrm{D}$ & $424.41 \mathrm{a}$ & $126.53 \mathrm{a}$ & $422.88 \mathrm{a}$ & $277.76 \mathrm{a}$ & $1.93 \mathrm{a}$ \\
P. major & $\mathrm{D}$ & $120.49 \mathrm{~b}$ & $-20.81 \mathrm{~b}$ & $136.91 \mathrm{~b}$ & $63.46 \mathrm{~b}$ & $7.71 \mathrm{a}$ \\
\hline
\end{tabular}

There is no significant difference among ratios followed by the same letter $(p<0.05)$ 
Table 6 Correlation coefficients between soil enzymes activity from root zone of $P$. major and P. lanceolata, root phosphatase activity, mycorrhizal colonization indices, and soil properties

\begin{tabular}{|c|c|c|c|c|c|c|c|c|c|c|}
\hline & $\begin{array}{l}\text { Acid } \\
\text { phosphatase }\end{array}$ & $\begin{array}{l}\text { Alkaline } \\
\text { phosphatase }\end{array}$ & Dehydrogenase & Urease & $\begin{array}{l}\text { Root acid } \\
\text { phosphatase }\end{array}$ & $\mathrm{F}$ & $\mathrm{M}$ & $\mathrm{m}$ & $\mathrm{a}$ & A \\
\hline \multicolumn{11}{|l|}{ Plantago major } \\
\hline $\mathrm{Cd}$ & 0.17 & $0.86^{*}$ & $0.86^{*}$ & $0.80 *$ & 0.52 & -0.51 & -0.49 & -0.45 & -0.09 & -0.35 \\
\hline $\mathrm{Cu}$ & $-0.67 *$ & 0.12 & 0.13 & 0.03 & -0.35 & -0.26 & $-0.77^{*}$ & $-0.77 *$ & -0.27 & -0.65 \\
\hline $\mathrm{Pb}$ & -0.06 & $0.72 *$ & $0.73 *$ & 0.65 & 0.31 & -0.47 & -0.61 & -0.57 & -0.14 & -0.45 \\
\hline $\mathrm{Fe}$ & 0.20 & $0.88^{*}$ & $0.88^{*}$ & $0.83^{*}$ & 0.55 & -0.52 & -0.48 & -0.43 & -0.06 & -0.32 \\
\hline $\mathrm{Mn}$ & 0.15 & $0.85^{*}$ & $0.85^{*}$ & $0.79 *$ & 0.50 & -0.50 & -0.50 & -0.45 & -0.10 & -0.35 \\
\hline $\mathrm{Zn}$ & 0.23 & $0.89 *$ & $0.89 *$ & $0.84 *$ & 0.57 & -0.51 & -0.46 & -0.41 & -0.09 & -0.33 \\
\hline Cdbio & -0.59 & 0.21 & 0.22 & 0.11 & -0.26 & -0.27 & -0.63 & -0.62 & -0.21 & -0.52 \\
\hline Mnbio & -0.21 & 0.57 & 0.58 & 0.50 & 0.11 & -0.27 & $-0.74 *$ & $-0.73 *$ & -0.13 & -0.52 \\
\hline Znbio & 0.17 & $0.86^{*}$ & $0.86^{*}$ & $0.80^{*}$ & 0.51 & -0.50 & -0.51 & -0.47 & -0.09 & -0.36 \\
\hline $\mathrm{pH}$ & $-0.69^{*}$ & 0.10 & 0.11 & 0.00 & -0.37 & -0.27 & $-0.73^{*}$ & $-0.72 *$ & -0.20 & -0.57 \\
\hline Organic matter content & 0.64 & $0.99 *$ & $1.00^{*}$ & $0.99 *$ & $0.85^{*}$ & -0.41 & -0.17 & -0.13 & -0.02 & -0.10 \\
\hline \multicolumn{11}{|l|}{ Plantago lanceolata } \\
\hline $\mathrm{Cd}$ & $0.85^{*}$ & $0.96^{*}$ & $0.97^{*}$ & $0.98^{*}$ & 0.37 & 0.12 & -0.26 & -0.28 & 0.03 & -0.11 \\
\hline $\mathrm{Cu}$ & $0.79 *$ & $0.92 *$ & $0.94 *$ & $0.95^{*}$ & 0.28 & 0.11 & -0.32 & -0.33 & -0.08 & -0.22 \\
\hline $\mathrm{Pb}$ & $0.74 *$ & $0.89^{*}$ & $0.91^{*}$ & $0.93 *$ & 0.20 & 0.06 & -0.24 & -0.25 & -0.10 & -0.20 \\
\hline $\mathrm{Fe}$ & $0.79 *$ & $0.92 *$ & $0.94 *$ & $0.95 *$ & 0.28 & 0.09 & -0.26 & -0.26 & -0.03 & -0.16 \\
\hline $\mathrm{Mn}$ & $0.90^{*}$ & $0.98^{*}$ & $0.99 *$ & $0.99 *$ & 0.46 & 0.19 & -0.27 & -0.29 & 0.10 & -0.06 \\
\hline $\mathrm{Zn}$ & $0.91 *$ & $0.99 *$ & $0.99 *$ & $1.00^{*}$ & 0.48 & 0.22 & -0.28 & -0.30 & 0.12 & -0.04 \\
\hline Cdbio & -0.63 & -0.42 & -0.37 & -0.34 & $-0.97^{*}$ & -0.43 & 0.12 & 0.18 & $-0.71 *$ & -0.50 \\
\hline Mnbio & $0.72 *$ & $0.87^{*}$ & $0.90^{*}$ & $0.91^{*}$ & 0.17 & 0.11 & -0.26 & -0.27 & -0.16 & -0.26 \\
\hline Znbio & $-0.67 *$ & -0.47 & -0.42 & -0.39 & $-0.97^{*}$ & -0.40 & 0.11 & 0.16 & $-0.71 *$ & -0.51 \\
\hline $\mathrm{pH}$ & 0.21 & 0.45 & 0.50 & 0.53 & -0.41 & -0.23 & -0.13 & -0.10 & -0.49 & -0.46 \\
\hline Organic matter content & $0.99 *$ & $0.96^{*}$ & $0.94 *$ & $0.93 *$ & $0.80^{*}$ & 0.39 & -0.26 & -0.31 & 0.46 & 0.23 \\
\hline
\end{tabular}

*Coefficient are statistically significant at $p<0.05$

toxic metals into biologically inactive forms. Those findings correspond with our results especially for the site affected by mining activity (D) (highest metal content, highest organic

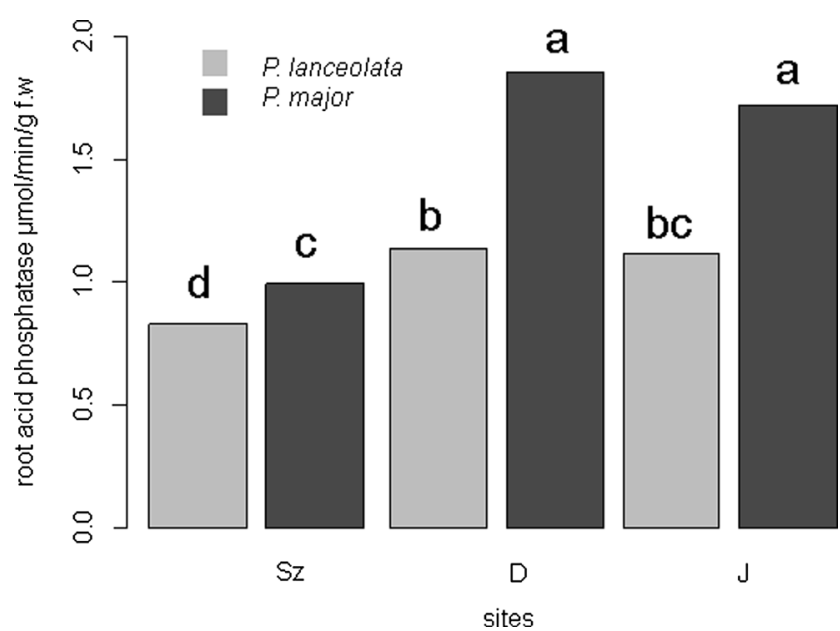

Fig. 2 Root acid phosphatase activity in Plantago species. The different letters denote significant differences between enzymes activity $(p<0.05)$ matter content and $\mathrm{pH}$, with the highest soil enzyme activity). On the other hand, Niemeyer et al. (2012) indicate that the main negative effect on microbial indicators, and among these soil enzymes, seems to be due to the limitation of plant reestablishment that results in low amounts of organic matter inputs to the soil. Such limitation of plant reestablishment was found in the area affected by smelting activity (Sz). This site is an example of an area on which infertility of the substratum (low organic matter), due to high bioavailable metal content, spontaneous revegetation is a very long process. The vegetation of this place is still in the early stage of succession. A higher organic matter content in the soil, as we found in the post mining area (D), supported greater soil enzyme activity not only by acting as sources of $\mathrm{C}$ for the soil microbial community but also due to the chelating effect protecting microorganisms and soil enzymes from excessive levels of metals in the soil (Lejon et al. 2010; Niemeyer et al. 2012). Tripathy et al. 2014 also found that all investigated soil enzymes were positively correlated with organic carbon, which indicates that enzyme activity is associated with organic fraction. Moreover, in the experiment 

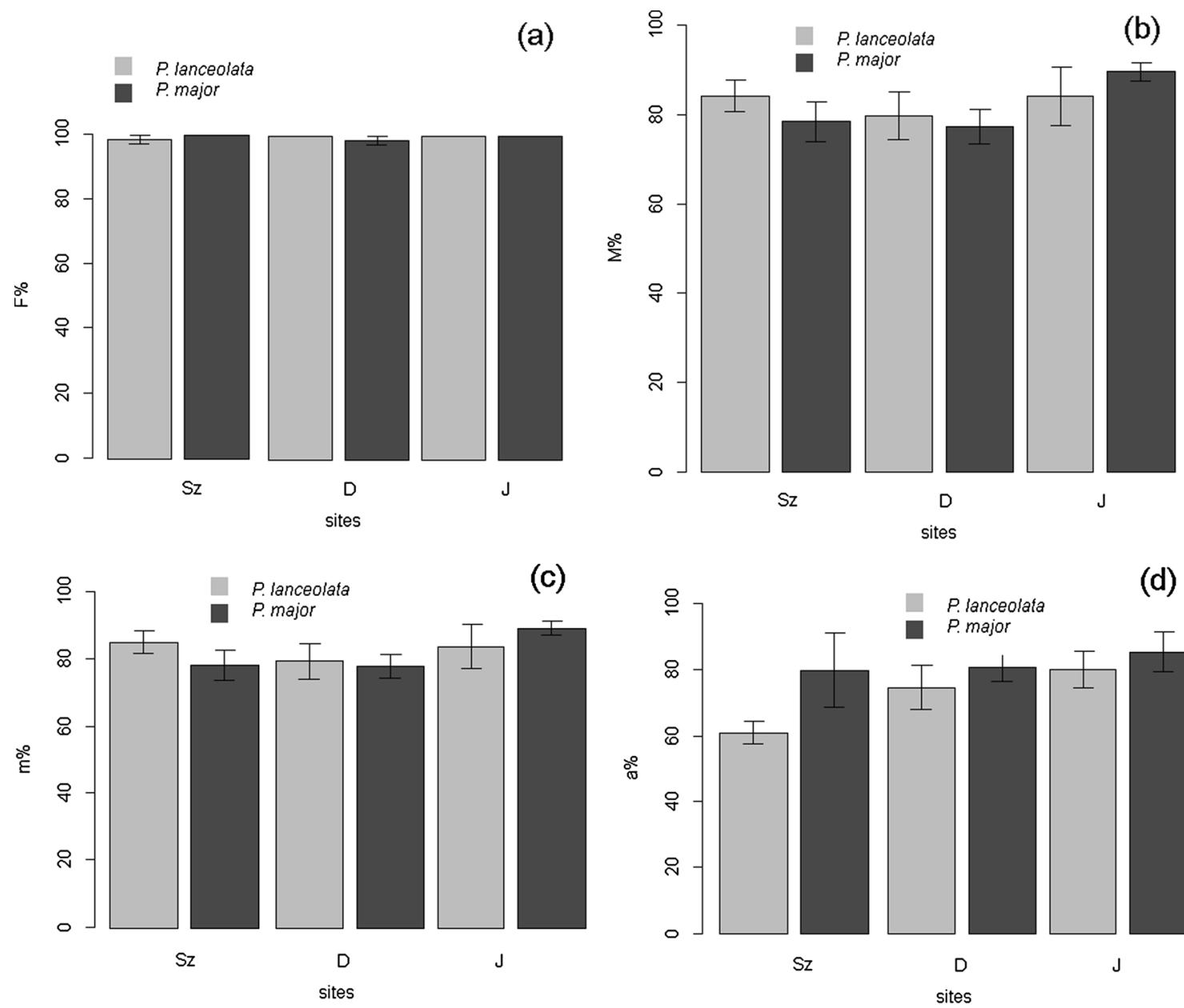

(c)

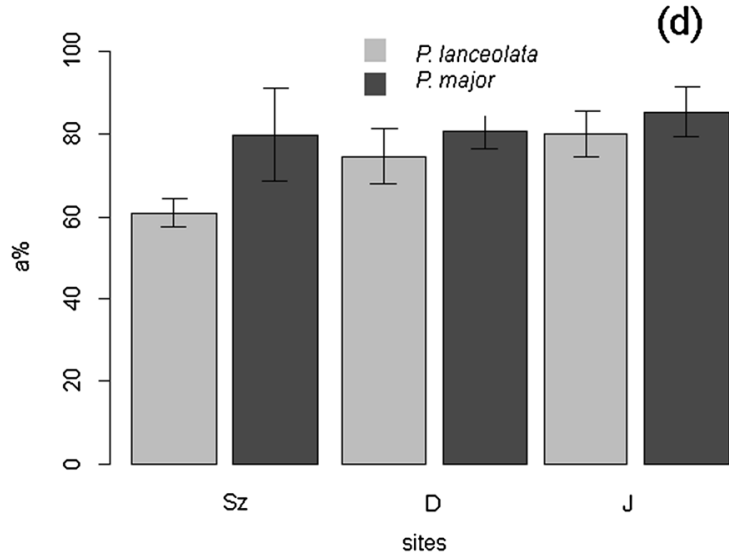

(e)

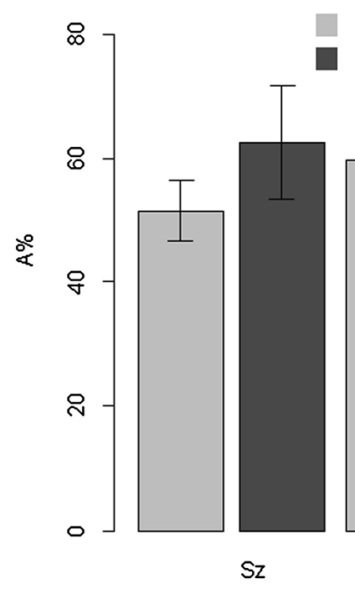

P. lanceolata P. major
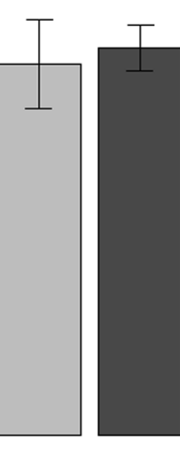

D

Fig. 3 Mycorrhizal colonization in Plantago species roots. a Mycorrhizal frequency (F \%), b relative mycorrhizal root (M \%), c the intensity of colonization within individual mycorrhizal roots $(\mathrm{m} \%)$, d

of Patel and Patra (2014), the increased activities of dehydrogenase, acid, and alkaline phosphatase in tannery sludge rich in heavy metals were presumably due to the high presence of organic matter. Water-soluble and exchangeable metal forms arbuscule richness in root fragments, where the arbuscules were present (a \%), e the relative arbuscular richness (A \%)

are generally more toxic than other forms because they can easily be released into water. The activity of soil microorganisms decreases as the levels of water-soluble and exchangeable metals increase (Tripathy et al. 2014). Accordingly, a negative 
correlation was found between bioavailable $\mathrm{Zn}$ and acid phosphatase activity in P. lanceolata root zone soil. Also, Wang et al. (2007) found negative correlations between soil phosphatase activity and $\mathrm{NH}_{4} \mathrm{NO}_{3}$ extractable heavy metals. Moreover, they suggested that soil microorganism activity and community composition could be predicted using the availability of $\mathrm{Cu}$ and $\mathrm{Zn}$. The negative ACRs values were computed for the area affected by smelting activity (Sz), confirming inhibition of soil enzyme activity. A similar statement on the usage of ACR in soil enzyme activity investigations was made for soil contaminated with $\mathrm{Pb}, \mathrm{Cd}$, and $\mathrm{As}$, in Xian et al. (2015). Generally, in our study in the soil root zone of $P$. lanceolata, phosphatase activity was higher in comparison to $P$. major in contaminated areas. This is in agreement with findings that different plant species can associate with microbial communities with unique characteristics probably due to differences in the amount and quality of root exudates (Yang et al. 2007). Moreover, it is also suggested that the coexistence of more plant species may alleviate $\mathrm{Pb}$ and $\mathrm{Cd}$ impacting on the activity of enzymes (Yang et al. 2010).

The fact that mycorrhizal colonization occurred in all of our in situ observations suggests a metal tolerance of local AM fungi. A well-developed mycorrhizal symbiosis may enhance the survival of plants in areas contaminated with heavy metals by better nutrient acquisition, water relations, pathogenic resistance, phytohormone production, and contribution to soil aggregation (Smith and Read 2008). Our study, a comparison of sites affected by smelting and mining activity and an uncontaminated control area, revealed no statistically significant differences in mycorrhizal colonization and arbuscule occurrence between $P$. lanceolata and $P$. major roots. This is in accordance with the findings of other authors (Ietswaart et al. 1992; Weissenhorn et al. 1995a, b; Rozpądek et al. 2014). There was no significant difference in mycorrhizal root colonization between populations of Agrostis capillaris growing on a sandy soil polluted by a smelter compared to limestone-derived clay with or without metals of natural origin (Ietswaart et al. 1992). High levels of mycorrhizal colonization were also observed in agricultural soils contaminated with metals from a smelter and sludge amendments (Weissenhorn et al. 1995a, b). A recent study in Poland demonstrated no statistically significant differences in mycorrhizal colonization (F\% 100, M\% 93-95, A\% 60-88) in chicory roots inoculated with Rhizophagus irregularis growing under the presence of toxic metals from industrial waste substratum from ZG Trzebionka and from non-polluted substrata (Rozpadek et al. 2014). The roots were in both cases almost fully colonized by the mycelium. On the other hand, metal-tolerant Oxalis acetosella colonizing forest soils treated with $\mathrm{Cd}, \mathrm{Zn}$, and $\mathrm{Pb}$ containing industrial dusts showed even higher AM colonization than non-treated soils (Turnau et al. 1996).
Our results demonstrated DSE colonization in both Plantago species in an area affected by mining activity (D) and in an uncontaminated stand (J). DSE is known to frequently colonize the roots of plants growing in heavy metal contaminated soil (Gucwa-Przepióra et al. 2013; Likar and Regvar 2013; Xu et al. 2015). Recently, Affholder et al. (2014) demonstrated that DSE may alleviate the toxicity of excess metal ions in host plants similarly to mycorrhizal fungi. However, in our investigation, DSE were not observed in the roots of $P$. lanceolata or $P$. major from a place affected by smelting activity (Sz), where the highest metal bioavailability was found. These results suggest that excessive concentrations of metals may reduce DSE occurrence in roots.

\section{Conclusions}

The area affected by smelting activity had a lower level of investigated soil enzymes, as well as a higher bioavailability of metals in the root zone soil of the Plantago species compared to the control site. Limitation of plant cover reestablishment, low organic matter in the soil as well as high bioavailable metal concentrations causes a decrease in enzyme activities. High organic matter concentration in the soil and a neutral or alkaline $\mathrm{pH}$ transform metals into biologically inactive forms. In this study, it was observed at the site affected by mining activity, where the highest soil enzymes activity was found.

Mycorrhizal colonization in both species in the contaminated areas was similar to the uncontaminated site. The lowest arbuscule occurrence was found in the area affected by smelting activity where the highest metal bioavailability was found. Moreover, DSE were not observed in the roots of the Plantago species in that stand, too. In pot experiments (in restricted conditions) conducted by other investigators, P. lanceolata AM indices were shown to be good indicators of soil heavy metal contamination. However, in our field study, such clear relations were not confirmed; this discrepancy shows that the problem needs further investigations.

The investigated Plantago species exhibited the excluder strategy and accumulated higher metals content in roots than in shoots. The accumulation in their shoots was comparable to other plants suggested as phytostabilizers in literature. The high tolerance to metals may be associated with a wellfunctioning mycorrhizal symbiosis observed in conditions that are highly injurious for plants. A decrease in the mycorrhizal colonization in contaminated sites was not observed in both plantains species. Due to the low accumulation of metals in shoots, as well as a high tolerance to metal contaminants, the selected Plantago species may be applied in the phytostabilization of heavy metal contaminated areas.

The combination of diverse monitoring approaches and the biological and physico-chemical methods in our study (assessment of enzyme activity, mycorrhizal colonization, and the 
chemical and physical properties of soils) proved to be sensitive to differences between sites and between Plantago species. This observation is very important in terms of land reclamation.

Open Access This article is distributed under the terms of the Creative Commons Attribution 4.0 International License (http:// creativecommons.org/licenses/by/4.0/), which permits unrestricted use, distribution, and reproduction in any medium, provided you give appropriate credit to the original author(s) and the source, provide a link to the Creative Commons license, and indicate if changes were made.

\section{References}

Addy HD, Piercey MM, Currah RS (2005) Microfungal endophytes in roots. Can J Bot 83:1-13

Aery NC (2010) Manual of environmental analysis. CRC Press, Taylor and Francis Group, Boca Raton, p 413

Affholder MC, Pricop AD, Laffont-Schwob I, Coulomb B, Rabier J, Borla A, Demelas C, Prudent P (2014) As, Pb, Sb, and Zn transfer from soil to root of wild rosemary: do native symbionts matter? Plant Soil 382:219-236

Bekteshi A, Bara G (2013) Uptake of heavy metals from Plantago major in the region of Durres, Albania. Pol J Environ Stud 22(6):18811885

Brundrett M (2002) Coevolution of roots and mycorrhizas of land plants. New Phytol 154(2):275-304

Carrasco L, Azcón R, Kohler J, Roldán A, Caravaca F (2011) Comparative effects of native filamentous and arbuscular mycorrhizal fungi in the establishment of an autochthonous, leguminous shrub growing in a metal-contaminated soil. Sci Total Environ 409:1205-1209

Ciarkowska K, Sołek-Podwika K, Wieczorek J (2014) Enzyme activity as an indicator of soil-rehabilitation processes at a zinc and lead ore mining and processing area. J Environ Manage 132:250-256

Dick RP (1997) Soil enzyme activities as integrative indicators of soil health. In: Pankhrust CE, Doube BM

Dimitrova I, Yurukova L (2005) Bioindication of anthropogenic pollution with Plantago lanceolata (Plantaginaceae): metal accumulation, morphological and stomatal leaf characteristics. Phytol Balcan 11(1):89-96

Ernst WHO (2005) Phytoextraction of mine wastes - options and impossibilities. Chem Erde-Geochem 65:29-42

Fernández DA, Roldán A, Azcón R, Caravaca F, Bååth E (2012) Effects of water stress, organic amendment and mycorrhizal inoculation on soil microbial community structure and activity during the establishment of two heavy metal-tolerant native plant species. Microb Ecol 63(4):794-803

Galal TM, Shehata HS (2015) Bioaccumulation and translocation of heavy metals by Plantago major L. grown in contaminated soils under the effect of traffic pollution. Ecol Indic 48:244-251

Gucwa-Przepióra E, Turnau K (2001) Arbuscular mycorrhiza and plant succession on zinc smelter spoil heap in Katowice-Wełnowiec. Acta Soc Bot Pol 70:153-158

Gucwa-Przepióra E, Małkowski E, Sas-Nowosielska A, Kucharski R, Krzyzak J, Kita A, Romkens PFAM (2007) Effect of chemophytostabilization practices on arbuscular mycorrhiza colonization of Deschampsia cespitosa ecotype Warynski at different soil depths. Environ Pollut 150(3):338-346

Gucwa-Przepióra E, Błaszkowski J, Kurtyka R, Małkowski Ł, Małkowski E (2013) Arbuscular mycorrhiza of Deschampsia cespitosa (Poaceae) at different soil depths in highly metalcontaminated site in southern Poland. Acta Soc Bot Pol 82:251-258

Ietswaart JH, Griffioen WAJ, Ernst WHO (1992) Seasonality of VAM infection in three populations of Agrostis capillaries (Gramineae) on soil with or without heavy metal enrichment. Plant Soil 139:67-73

Jumpponen A (2001) Dark septate endophytes - are they mycorrhizal? Mycorrhiza 11:207-211

Jumpponen A, Trappe JM (1998) Dark septate endophytes: a review of facultative biotrophic root colonizing fungi. New Phytol 140:295-310

Kabata-Pendias A (2001) Trace elements in soils and plants, 3rd edn. CRC Press, Boca Raton, p 397

Kieliszewska-Rokicka B (2001) Soil enzymes and their importance in soil microbial activity estimation. In: Dahm H, Pokojska-Burdziej A (eds) Drobnoustroje środowiska glebowego. Aspekty fizjologiczne, biochemiczne, genetyczne. Wydawnictwo Adam Marszałek, Toruń, pp 37-47 (in Polish)

Lejon DPH, Pascault N, Ranjard L (2010) Differential copper impact on density, diversity and resistance of adapted culturable bacterial population according to soil organic status. Eur J Soil Biol 46:168-174

Leung HM, Ye ZH, Wong MH (2007) Survival strategies of plants associated with arbuscular mycorrhizal fungi on toxic mine tailings. Chemosphere 66:905-915

Likar M, Regvar M (2013) Isolates of dark septate endophytes reduce metal uptake and improve physiology of Salix caprea L. Plant Soil 370:593-604

Markert B, Wuenschmann S, Fraenzle S, Wappelhorst O, Weckert V, Breulmann G, Djingova R, Herpin U, Lieth H, Schroeder W, Siewers U, Steinnes E, Wolterbeek B, Zechmeister H (2008) On the road from environmental biomonitoring to human health aspects: monitoring atmospheric heavy metal deposition by epiphytic/epigeic plants: present status and future needs. Int J Environ Pollut 32:486-498

Nadgórska A, Kandziora-Ciupa M, Ciepał R (2015) Element accumulation, distribution, and phytoremediation potential in selected metallophytes growing in a contaminated area. Environ Monit Asses 187:441. doi:10.1007/s10661-015-4680-6

Nadgórska-Socha A, Łukasik I, Ciepał R, Pomierny S (2006) The activity of selected enzymes in soil loaded with varied heavy metals level. Acta Agrophysica 8(3):713-725

Nadgórska-Socha A, Ptasiński B, Kita A (2013) Heavy metal bioaccumulation and antioxidative responses in Cardaminopsis arenosa and Plantago lanceolata leaves from metalliferous and nonmetalliferous sites: a field study. Ecotoxicology 22:1422-1434

Niemeyer JC, Bortoti Lolata G, Martins de Carvalho G, Mendes Da Silva E, Paulo Sousa J, Nogueirac MA (2012) Microbial indicators of soil health as tools for ecological risk assessment of a metal contaminated site in Brazil. Appl Soil Ecol 59:96-105

Nouri J, Khorasani N, Lorestani B, Karami M, Hassani H, Yousefi N (2009) Accumulation of heavy metals in soil and uptake by plants species with phytoremediation potential. Environ Earth Sci 59:315-323

Olowoyo JO, Okedeyi OO, Mkolo NM, Lion GN, Mdakane STR (2012) Uptake and translocation of heavy metals by medicinal plants growing around a waste dump site in Pretoria, South Africa. S Afr J Bot $78: 116-121$

Orłowska E, Zubek Sz, Jurkiewicz A, Szarek-Lukaszewska G, Turnau K (2002) Influence of restoration on arbuscular mycorrhiza of Biscutella laevigata L. (Brassicaceae) and Plantago lanceolata L. (Plantaginaceae) from calamine spoil mounds. Mycorrhiza 12:153-160

Orłowska E, Ryszka P, Jurkiewicz A, Turnau K (2005) Effectiveness of arbuscular mycorrhizal fungal (AMF) strains in colonisation of plants involved in phytostabilisation of zinc wastes. Geoderma 129(1-2):92-98 
Orłowska E, Godzik B, Turnau K (2012) Effect of different arbuscular mycorrhizal fungal isolates on growth and arsenic accumulation in Plantago lanceolata L. Environ Pollut 168:121-130

Ostrowska A, Gawliński S, Szczubiałka Z (1991) Method of analysis and estimate soil and plants property, Catalogue of theEnvironmental Protection Institute Warsaw, p 334 (in Polish)

Patel A, Patra DD (2014) Influence of heavy metal rich tannery sludge on soil enzymes vis-à-vis growth of Tagetes minuta an essential oil bearing crop. Chemosphere 112:323-332

Pérez de Mora A, Ortega-Calvo JJ, Cabrera F, Madejón E (2005) Changes in enzyme activities and microbial biomass after "in situ" remediation of a heavy metal-contaminated soil. Appl Soil Ecol 28: $125-137$

Phillips JM, Hayman DS (1970) Improved procedures for clearing roots and staining parasitic and vesicular-arbuscular mycorrhizal fungi for rapid assessment of infection. Trans Brit Myc Soc 55:158-160

Piercey MM, Graham SW, Currah RS (2004) Patterns of genetic variation in Phialocephala fortinii across a broad latitudinal transect in Canada. Mycol Res 108:955-964

R Core Team (2014) R: A language and environment for statistical computing. R Foundation for Statistical Computing, Vienna, Austria. URL http://www.R-project.org/Regulation of the Polish Minister of Environment (dated 9 September 2002) Official Gazette No. 165, Pos. 1359th. (in Polish)

Rozpądek P, Wężowicz K, Stojakowska A, Malarz J, Surówka E, Sobczyk Ł, Anielska T, Ważny R, Miszalski Z, Turnau K (2014) Mycorrhizal fungi modulate phytochemical production and antioxidant activity of Cichorium intybus L. (Asteraceae) under metal toxicity. Chemosphere 112:217-224

Schinner F, Öhlinger R, Kandeler E, Margensin R (1995) (eds) Methods in soil biology. Springer, Berlin, p 426

Schüßler A, Schwarzott D, Walker C (2001) A new fungal phylum, the Glomeromycota: phylogeny and evolution. Mycol Res 105: 1413-1421

Serbula SM, Miljkovic DD, Kovacevic RM, Ilic AA (2012) Assessment of airborne heavy metal pollution using plant parts and topsoil. Ecotox Environ Safe 76:209-214

Smith SE, Read D (2008) Mycorrhizal symbiosis, 3rd edn. Academic, New York, p 800

Tamás J, Kovács A (2005) Vegetation pattern and heavy metal accumulation at a mine tailing at Gyöngyösoroszi, Hungary. Z Naturforsch C 60(3-4):362-367
Tripathy S, Bhattacharyy P, Mohapatrac R, Som A, Chowdhury D (2014) Influence of different fractions of heavy metals on microbial ecophysiological indicators and enzyme activities in century old municipal solid waste amended soil. Ecol Eng 70:25-34

Trouvelot A, Kough JL, Gianinazzi-Pearson V (1986) Mesure du taux de mycorhization VA d'un systeme radiculaire. Recherche de methodes d'estimation ayant une signification fonctionnelle. In: GianinazziPearson V, Gianinazzi S (eds) Physiological and genetical aspects of mycorrhizae. INRA, Paris, pp 217-221

Turnau K, Miszalski Z, Trouvelot A, Bonfante P, Gianinazzi S (1996) Oxalis acetosella as a monitoring plant on highly polluted soils. In: Azcon-Aguilar C, Barea JM (eds) Mycorrhizas in integrated systems from genes to plant development. European Commission, Brussels, pp 483-486

Wang Y, Shi J, Lin Q, Chen X, Chen Y (2007) Heavy metal availability and impact on activity of soil microorganisms along a $\mathrm{Cu} / \mathrm{Zn}$ contamination gradient. J Environ Sci 19:848-853

Weissenhorn I, Leyval C, Belgy G, Berthelin J (1995a) Arbuscular mycorrhizal contribution to heavy metal uptake by maize (Zea mays L.) in pot culture with contaminated soil. Mycorrhiza 5:245-251

Weissenhorn I, Leyval C, Berthelin J (1995b) Bioavailability of heavy metals and abundance of arbuscular mycorrhiza in a soil polluted by atmospheric deposition from a smelter. Biol Fert Soils 19:22-28

Wójcik M, Sugier P, Siebielec G (2014) Metal accumulation strategies in plants spontaneously inhabiting $\mathrm{Zn}-\mathrm{Pb}$ waste deposits. Sci Total Environ 487:313-322

Xian Y, Wanga M, Chena W (2015) Quantitative assessment on soil enzyme activities of heavy metal contaminated soils with various soil properties. Chemosphere 139:604-608. doi:10.1016/j. chemosphere.2014.12.060

Xu R, Li T, Cui H, Wang J, Yu X, Ding Y, Wang C, Yang Z, Zhao Z (2015) Diversity and characterization of Cd-tolerant dark septate endophytes (DSEs) associated with the roots of Nepal alder (Alnus nepalensis) in a metal mine tailing of southwest China. Appl Soil Ecol 93:11-13

Yang R, Tang J, Chen X, Hu S (2007) Effects of coexisting plant species on soil microbes and soil enzymes in metal lead contaminated soils. Appl Soil Ecol 37:240-246

Yang Q, Luo K, Li XM, Wang DB, Zheng W, Zeng GM, Liu JJ (2010) Enhanced efficiency of biological excess sludge hydrolysis under anaerobic digestion by additional enzymes. Bioresource Technol 101(9):2924-2930 